Regular Article

ISSN 2287-2396

Journal of Forest Science

Vol. 29, No. 2, pp. 147-156, May, 2013

http://dx.doi.org/10.7747/JFS.2013.29.2.147

\title{
Economic Analysis of Growing Ginger (Zingiber officinale) Under Teak (Tectona grandis) Canopy in Southwest Nigeria
}

\author{
Adekunle Tajudeen Oladele ${ }^{1, *}$ and Labode Popoola ${ }^{2}$ \\ ${ }^{1}$ Department of Forestry and Wildlife Management, University of Port Harcourt, Port Harcourt 500001, Nigeria \\ ${ }^{2}$ Department of Forest Resources Management, University of Ibadan, Ibadan 900001, Nigeria
}

\begin{abstract}
Multiple use forestry is capable of generating income for forest based communities through Non-Timber forest products (NTFPs) which provide food, medicine, materials for domestic use and cash income for communities adjoining forest areas in developing countries. This study evaluates the economics of producing ginger rhizomes under teak canopy in a multiple land use system during 2007 and 2008 in even aged teak plantations in Ibadan and Ife, Nigeria. Twelve $6 \mathrm{~m}^{2}$ sample plots were randomly selected in Completely Randomized Block Design within and outside the plantation. Average ginger rhizome of (50-60 g) were planted on the slightly tilled soil. NPK 15:15:15 was applied at 180 kg/ha on a split unit dose. ANOVA, Profitability, Benefit-Cost $(\mathrm{B} / \mathrm{C})$ ratio were used to analyze data. Results showed no significant differences between sites in ginger rhizome yield, $(0.089$ and $0.718, \rho \leq 0.05)$ in 2007 and 2008 respectively. Average yield were higher outside teak canopy in both sites and treatments, (Ibadan $-40.05 \mathrm{~g}>32.9 \mathrm{~g}$, Ife $-67.6 \mathrm{~g}>25.2 \mathrm{~g}$ and Ibadan $-41.3 \mathrm{~g}>31.5 \mathrm{~g}$, Ife $-66.8 \mathrm{~g}>25.0 \mathrm{~g}$ ) with and without NPK respectively. NPK had no effect on yields within teak plantation, (Ibadan $-31.5<32.9$ $\mathrm{g}$, Ife $-25 \mathrm{~g}<25.2 \mathrm{~g}$ ). Ginger rhizome production was viable financially without inorganic fertilizer during second cropping season within and outside plantation $(\mathrm{B} / \mathrm{C}=1.02,1.09)$ respectively. Ginger could be raised profitably under teak canopy, however, studies on insolation requirement of ginger under teak canopy and other tree plantations are recommended.
\end{abstract}

Key Words: ginger rhizome yield, teak, profitability, benefit cost ratio, sensitivity, nigeria

\section{Introduction}

Non-timber forest products (NTFPs) issues have attracted considerable global interest in recent years (Chukwuone and Okorji 2008). These products provide food, medicine and materials for domestic use, while some of them also provide cash income when traded in local, national or international markets (Clark 2001). It is now generally recognized that NTFPs play important role in forests edge communities' economy, since they are used for subsistence and sometimes for sale, providing cash income (Adepoju and Salau 2007). Production of sufficient NTFPs alongside timber in a multiple land use system could make the forest deliver a return higher in value than the value of alternative land uses. As more agricultural land becomes degraded and unproductive through the adoption of inappropriate technologies, more forestland is cleared of trees and more unproductive land created in addition to ever-increasing pressure on land caused by population increase, industrialization, urbanization and mineral exploitation. This ugly develop-

Received: October 21, 2012. Revised: March 11, 2013. Accepted: 월 0, 2013.

Corresponding author: Adekunle Tajudeen Oladele

Department of Forestry and Wildlife Management, University of Port Harcourt, Port Harcourt 500001, Nigeria

Tel: 234-805-6021267, E-mail: adekunle.oladele@uniport.edu.ng, kunleladele@yahoo.com 
ment calls for a more selective approach, with emphasis on those small farming systems or phases of development in plantation forestry where intercropping of food and tree crops as well as medicinal plants can be of definite technical and economic benefit (John 1980).

This system will in no small measure encourage community participation in the management of forest plantations adjoining their communities. NTFPs are important factors in forest management but their production have been historically neglected by forest managers (Amusa et al. 2012) hence; detailed studies on the NTFP production after canopy closure in plantation projects are limited, especially in Nigeria. Production of NTFPs within forest crop plantations and natural forests is an area researchers need to focus for breakthrough in sustainable NTFPs production globally.

Amongst major problems of forest plantations in sub Saharan West Africa is the accumulated interest on capital for forest plantation establishment and maintenance: these are enormous and represent hindrances in its development, due to long rotation age of forest plantation projects (Brown 2000; Krishnapillay 2002). Loan servicing and repayment problems encountered in plantation projects remain major setbacks for the development and management of forestry activities especially in the developing countries. Most of forest plantation investments were donor - driven and supported (either as grants or loans), and many were successfully established but could not be sustained when the support ceased due to poor management. This has led to low fund attraction from both local and international funding agencies.

In the past, taungya systems have been employed to reduce plantation establishment cost, however, this system is limited as the forest plantation canopy closes. The food crops were normally cultivated for three years, after which the shade from the trees impeded further cultivation of the crops (Agyeman et al. 2003). Johnson (1980) observed that plantation owners, have little concerned for annual crops except in the case of intercropping during the early stages of plantation establishment.

Across the tropics, Tectona grandis have grown well and are widely planted for saw logs, chips, and poles production. The financial and economic requirements of the plantation during the waiting period (between canopy closure and rotation age) remain a major hurdle or setback which this work attempts to address. Growing economically viable annuals or biennials that are compatible with plantation ecosystems may prove suitable in solving this problem.

Ginger (Zingiber officinale Roscoe, Family: Zingiberaceae) is largely consumed as spice and also contained volatile oil used as flavour, aromatic stimulant and carminative in pharmaceutical industry (Tyler et al. 1981). Locally in West Africa it is used chiefly for medicinal and veterinary purposes, for catarrhal conditions, pains of rheumatism, toothache, neuralgia, nausea, motion sickness, migraine, dyspepsia, and to reduce flatulence and colic. Young rhizomes that are harvested early are also used in pickles and confectionery (Valenzuela 2011).

Ginger is capable of generating farmer's income, creating employment opportunities and earning foreign exchange. Sabur et al. (1998) observed that Ginger gave high yields when intercropped and is an ideal shade crop under Paulownnia elongata plantations in China. This work investigates the economics of growing ginger under canopies of Tectona grandis.

\section{Materials and Methods}

\section{Study sites}

The study areas are located in between the humid and sub-humid tropical climates with mean annual rainfall of approximately $1,200 \mathrm{~mm}$; Its' rainfall has a characteristic bimodal distribution with peaks usually in June or July and September, and a period of low precipitation in August, with four months of dry season (December-March). Annual temperature ranges from an average minimum of $24.6^{\circ} \mathrm{C}$ to average maximum of $31.5^{\circ} \mathrm{C}$ (Agbola and Ojeleye 2007).

\section{Ibadan}

Experimental site lies northwest of the University of Ibadan campus at approximately $7^{\circ} 30^{\prime} \mathrm{N}$ latitude and longitude $3^{\circ} 54^{\prime} \mathrm{E}$. The Tectona grandis stand was established in 1985 by the Department of Forest Resources Management, University of Ibadan. Tectona grandis was planted in rows of $6 \mathrm{~m}$ spacing and $3 \mathrm{~m}$ along each row (Adesoye and Oluwadare 2010). The stands are of even-age with relatively close-canopy and pockets of openings allowing enough light to support the undergrowths. 


\section{I/e-Ife}

The Teak plantation is located within the Teaching and Research Farm of the Obafemi Awolowo University, IleIfe, Osun State on latitude $7^{\circ} 28^{1} \mathrm{~N}$ and longitude $4^{0} 33^{1} \mathrm{E}$. The plantation was established in 1983 for pole production for the university. Spacing is $6 \mathrm{~m}$ by $3 \mathrm{~m}$. It is an even-aged plantation with relatively closed canopy that allows some degree of insolation at the forest floor.

\section{Experimental design}

Twenty four $\left(6 \mathrm{~m}^{2}\right)$ plots were randomly located within and outside the plantation. A minimum distance of $10 \mathrm{~m}$ was allowed between plots while minimum of $3 \mathrm{~m}$ was allowed between sub plots. Completely Randomized Block Design (CRBD) was employed in the study. Tree counts were carried out in the selected plantation plots with average of 14.8 trees per plot. Any plot with large variance in diameter at breast height $(\mathrm{dbh})$ of $( \pm 3 \mathrm{~cm})$ to the mean tree was discarded. Plots were tilled manually in and outside the plantation. The distance of the outside plot from the edge of plantation was 10 metres; this was to prevent the shading effect of the plantation. Average ginger rhizome fingers of 50-60 $\mathrm{g}$ were planted (90 $\mathrm{cm}$ by $60 \mathrm{~cm}$ ) and NPK 15:15:15 fertilizer was applied at $180 \mathrm{~kg} /$ ha following recommended base rates by Lee et al. (1981). The treatments were applied on a split unit dose at two and six weeks, by drilling beside the ginger plant on the ridges. Beating up was carried out to replace lost seedlings on the field after planting. The ginger rhizomes were harvested at the age of 32 weeks each year. The study was conducted in 2007 and 2008 cropping seasons.

\section{Data analytical tools}

Cultural operations costs such as land clearing, tilling, weeding, cost of ginger propagules and fertilizer were computed for profitability analysis. Current market price was used to compute revenue from the ginger rhizomes.

\section{Mean Yield of ginger-Completely Randomized Block Design (CRBD)}

$$
\mathrm{Y}_{\mathrm{ij}}=\mu+\mathrm{t}_{\mathrm{ij}}+\mathrm{E}_{\mathrm{ijk}}
$$

Where: $Y_{i j}=$ Yield per plot, $j=$ No of plots in a treatment, $\mu=$ General mean, $T_{i j}=$ Effect of treatment, $E_{i j}=$ Associated error term.

Analysis of variance (ANOVA) at 5\% probability level was computed and Fisher's Least Significant Difference (LSD) used to separate means with significant differences.

The mean yield of ginger rhizome under canopy system was compared to the mean yield of control experiment using Student's T-test

$$
t=\frac{\overline{X_{A}}+\overline{X_{B}}}{\sqrt{\frac{S^{2}\left(n_{A}+n_{B}\right)}{\left(n_{A}\right)\left(n_{B}\right)}}}
$$

\section{Profitability analysis}

The profitability analysis of growing ginger in teak plantation was carried out using:

$$
\operatorname{Pr}=\mathrm{T}_{\mathrm{r}}-\mathrm{T}_{\mathrm{c}}
$$

Where $P_{r}=$ Profit, $T_{r}=$ Total Revenue (Naira value), $T_{c}=$ Total Cost (inputs + labour)

\section{Benefit Cost Ratio}

Benefit cost ratio was used to evaluate the economic performance of the experiment over the two years of cultivation;

$$
B C=\frac{\sum_{i=0}^{n} B_{t} /(1+r)^{2}}{\sum_{i=0}^{n} C_{t} /(1+r)^{2}}
$$

Where: $B_{t}=$ Benefit in year $t$ (direct benefits in terms of yield), $I=$ Interest/discount rate, $T=$ no of years from $0, C=$ Cost

\section{Results}

\section{Total and average rhizome yield of ginger in Ibadan and Ife}

Ginger stands under forest cover without fertilizer (C-33.86 g) yielded higher rhizomes than stands treated with fertilizer (A-23.74 g) in the first cropping season (Table 1). Plots outside canopy treated with NPK have a higher yield (B-59.14 g) than those without NPK (D-54.91 g). However, in year 2, plot treated with fertilizer under forest estate has the highest average yield of $37.36 \mathrm{~g}$, 
Table 1. Total and average ginger rhizome yields in ibadan and ife sites

\begin{tabular}{|c|c|c|c|c|c|c|c|c|c|}
\hline \multirow{2}{*}{ Year } & \multirow{2}{*}{ Ginger yield } & \multicolumn{4}{|c|}{ Ibadan } & \multicolumn{4}{|c|}{ Ife } \\
\hline & & Plot A & Plot B & Plot C & Plot D & Plot A & Plot B & Plot C & Plot D \\
\hline 1 & Total yield/plot (kg) & 9.21 & 1.95 & 13.72 & 21.30 & 5.28 & 30.59 & 5.54 & 20.95 \\
\hline 1 & Average yield/stand (g) & 23.74 & 59.14 & 33.86 & 54.91 & 14.84 & 78.04 & 15.08 & 58.52 \\
\hline 2 & Total yield/plot (kg) & 14.50 & 4.10 & 11.88 & 12.67 & 5.83 & 6.26 & 8.61 & 17.36 \\
\hline 2 & Average yield/stand (g) & 37.36 & 14.16 & 30.79 & 35.10 & 18.26 & 34.39 & 22.95 & 56.53 \\
\hline
\end{tabular}

Plot A, Ginger plot under Forest estate (Pure Teak) treated with fertilizer; Plot B, Ginger plot outside forest estate treated with fertilizer; Plot C, Ginger plot under forest estate (Teak) without fertilizer; Plot D, Ginger plot outside forest estate without fertilizer. Aberrations in Ibadan result due to disturbances from the local community and fire outbreak in the plantation. Source: Field experiment, 2007 and 2008.

Table 2. Comparative mean yields of ginger in Ibadan and Ife sites $(\rho \leq 0.05)$

\begin{tabular}{lccccc}
\hline \multicolumn{1}{c}{ Location } & Mean & T value & df & Sig. & Remark \\
\hline Ibadan Year 1 and 2 & 9.2996 & 9.244 & 1,360 & 0.000 & Sig \\
Ife Year 1 and 2 & 3.4173 & 2.675 & 1,096 & 0.008 & Sig \\
Ibadan year 1 and Ife year 1 & 2.0563 & 1.700 & 1,398 & 0.089 & Not Sig \\
Ibadan year 2 and Ife year 2 & -0.4108 & -0.361 & 1,087 & 0.718 & Not Sig \\
Ibadan year 1 and Ife year 2 & 7.6883 & 6.471 & 1,147 & 0.000 & Sig \\
Ibadan year 2 and Ife year 1 & -9.3703 & -7.045 & 1,314 & 0.000 & Sig \\
\hline
\end{tabular}

Source: Field experiment, 2007 and 2008.

and $35.10 \mathrm{~g}, 30.79 \mathrm{~g}$ and $14.16 \mathrm{~g}$ respectively for plots A, $\mathrm{D}, \mathrm{C}$ and $\mathrm{B}$. The aberration recorded in plot $\mathrm{B}$ yield is as a result of disturbance by the community farmers/hunters that set the plot on fire, however first year yields are comparable to results from the other site (Ife).

Ife year one yields in plots A (14.84 g) and C (15.08 g) are similar and very low compared to ginger yields in plots $\mathrm{B}$ (78.04 g) and D (58.52 g). This is an indication that the Teak plantation exerted negative impacts on rhizome production in ginger (Table 1). Year 2 average yields (Ife) were highest in plots outside forest cover, D (56.53 g) and B $(34.39 \mathrm{~g})$ respectively, while the average yields in plots under forest cover C (22.95 g) higher than A (18.26 g).

\section{Comparative means of ginger rhizome yields in Ibadan and Ife sites}

Paired Sample T-test showed significant differences in the mean yields of ginger rhizome at Ibadan (0.000) and Ife (0.008) sites (within sites) for two years. However, there were no significant differences between sites for two years (0.089 and 0.718). Similar results were obtained in the two

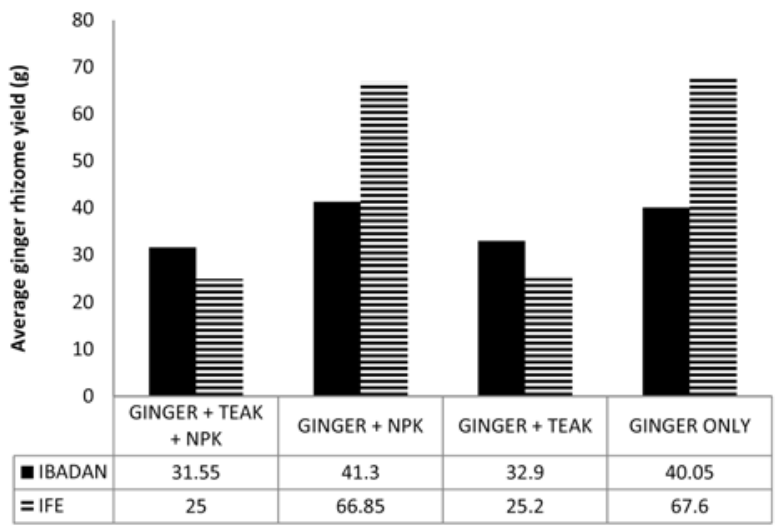

Fig. 1. Effect of teak canopy and NPK fertilizer on ginger rhizome yield in south west Nigeria

sites (Table 2).

\section{Effect of teak canopy and NPK fertilizer on ginger rhizome yield}

Average ginger rhizome yields were lower in plots located within teak canopy in the two sites (Fig. 1), applica- 
tion of NPK fertilizer to ginger under forest cover do not yield higher rhizomes in ginger (Ibadan-32.9>31.55 g, Ife-25.2> $25 \mathrm{~g}$ ), however, NPK fertilizer slightly increased rhizome yields in plots outside teak canopy at Ibadan site $(41.3>40.05 \mathrm{~g})$, rhizome yields were higher in fertilizer plots outside teak canopy in Ife $(67.6>66.85 \mathrm{~g})$.

\section{Profitability analysis of ginger grown under and out- side teak plantations in Ibadan}

Ginger rhizome production was observed to be profitable under teak canopy without NPK fertilizer treatment $(\mathrm{N} 18.8 \mathrm{k})$ and sole production of ginger rhizome outside teak canopy (N82.00) in the second cropping season in Ibadan (Table 3).

\section{Benefit Cost analysis of ginger grown under and outside teak plantations in Ibadan}

Benefit Cost (B/C) analysis (Table 4) showed that ginger rhizome yield is financially viable under teak canopy $(\mathrm{B} / \mathrm{C}=1.02)$ in second year, ginger grown outside canopy in second year $(\mathrm{B} / \mathrm{C}=1.09)$ and plot treated with NPK fertilizer under teak canopy $(\mathrm{B} / \mathrm{C}=0.97)$ in second year were also viable. All other treatments were not viable financially for ginger rhizome production since $\mathrm{B} / \mathrm{C}$ ratios were less than 1 .

Sensitivity analysis of Benefit Cost ratios $(B / C)$ and Net Present Values (NPV) of ginger rhizome production in teak plantation in Ibadan

Benefit Cost analysis (Table 5) revealed three viable treat-

Table 3. Profitability of ginger rhizome yield $\left(648 \mathrm{~m}^{2}\right)$ in and outside teak plantation in ibadan

\begin{tabular}{|c|c|c|c|c|c|c|c|c|c|c|}
\hline \multirow[b]{2}{*}{ Treatments } & \multirow[b]{2}{*}{ Year } & \multicolumn{6}{|c|}{ Costs } & \multicolumn{3}{|c|}{ Benefits } \\
\hline & & $\begin{array}{c}\text { Land } \\
\text { preparation }\end{array}$ & $\begin{array}{l}\text { Planting } \\
\text { stock }\end{array}$ & Weeding & $\begin{array}{c}\text { NPK } \\
\text { fertilizer }\end{array}$ & Harvesting & Total cost & $\begin{array}{l}\text { Rhizome } \\
\text { yield }(\mathrm{kg})\end{array}$ & $\begin{array}{c}\text { Sales price } \\
(80 / \mathrm{kg})\end{array}$ & $\begin{array}{l}\text { Profit } \\
\text { margin }\end{array}$ \\
\hline \multirow{2}{*}{$\begin{array}{l}\text { Teak + ginger } \\
+ \text { NPK }\end{array}$} & 1 & 2,700 & 231.60 & 300 & 256.74 & 200 & $3,688.34$ & 9.21 & 736.80 & -2951.54 \\
\hline & 2 & 200 & 231.60 & 300 & 256.74 & 200 & $1,188.34$ & 14.50 & $1,160.00$ & -28.34 \\
\hline \multirow[t]{2}{*}{ Teak + ginger } & 1 & 2,700 & 231.60 & 300 & - & 200 & $3,431.60$ & 13.72 & $1,097.60$ & $-2,334.00$ \\
\hline & 2 & 200 & 231.60 & 300 & - & 200 & 931.60 & 11.88 & 950.40 & 18.8 \\
\hline \multirow[t]{2}{*}{ Ginger+NPK } & 1 & 2,700 & 231.60 & 300 & 261.36 & 200 & $3,692.96$ & 1.95 & 156.00 & $-3,536.96$ \\
\hline & 2 & 200 & 231.60 & 300 & 261.36 & 200 & $1,192.96$ & 4.10 & 328.00 & -864.96 \\
\hline \multirow[t]{2}{*}{ Ginger only } & 1 & 2,700 & 231.60 & 300 & - & 200 & $3,431.60$ & 21.30 & $1,704.00$ & $-1,727.6$ \\
\hline & 2 & 200 & 231.60 & 300 & - & 200 & 931.60 & 12.67 & $1,013.60$ & 82.00 \\
\hline
\end{tabular}

$\mathrm{USD} \$ 1=\mathrm{N} 150$ (Nigeria Naira).

Table 4. Benefit cost analysis of ginger rhizome yield per $\left(648 \mathrm{~m}^{2}\right)$ under and outside teak plantation in ibadan

\begin{tabular}{lccccccccccc}
\hline Treatments & Year & $\begin{array}{c}\text { Total } \\
\text { cost }\end{array}$ & $\begin{array}{c}\text { Total } \\
\text { benefit } \\
(80 / \mathrm{kg})\end{array}$ & $\begin{array}{c}\text { Discount } \\
\text { rate }\end{array}$ & $\begin{array}{l}\text { Discounted } \\
\text { factor }\end{array}$ & $\begin{array}{c}\text { Discounted } \\
\text { cost }\end{array}$ & $\begin{array}{c}\text { Discounted } \\
\text { benefit }\end{array}$ & B/C & RORI & NPV \\
\hline Teak+ ginger & 1 & $3,688.34$ & 736.8 & 0.8772 & 1.8772 & $1,964.80929$ & 392.4994673 & 0.199765 & -80.0235 & $-1,572.31$ \\
+ NPK & 2 & $1,188.34$ & 1,160 & 0.7695 & 3.1311303 & 379.5242948 & 370.47325 & $0.976152^{*}$ & -2.38484 & -9.05104 \\
Teak+ginger & 1 & $3,431.6$ & $1,097.6$ & 0.8772 & 1.8772 & $1,828.041764$ & 584.7006179 & 0.319851 & -68.0149 & $-1,243.34$ \\
& 2 & 931.6 & 950.4 & 0.7695 & 3.1311303 & 297.5283446 & 303.5325662 & $1.02018 *$ & 2.018033 & 6.004222 \\
Ginger+PK & 1 & $3,692.96$ & 156 & 0.8772 & 1.8772 & $1,967.270403$ & 83.10249307 & 0.042243 & -95.7757 & $-1,884.17$ \\
& 2 & $1,192.96$ & 328 & 0.7695 & 3.1311303 & 380.9998003 & 104.7545052 & 0.274946 & -72.5054 & -276.245 \\
Ginger only & 1 & $3,431.6$ & 1,704 & 0.8772 & 1.8772 & $1,828.041764$ & 907.7349244 & 0.496561 & -50.3439 & -920.307 \\
& 2 & 931.6 & $1,013.6$ & 0.7695 & 3.1311303 & 297.5283446 & 323.7169709 & $1.088021 *$ & 8.802061 & 26.18863 \\
\hline
\end{tabular}

The current (2011) Central Bank of Nigeria (CBN) discount rate approved for agricultural based investment was used in the calculation. 
Table 5. Sensitivity analysis of decreasing production cost of ginger in teak plantation at ibadan $(\mathrm{B} / \mathrm{C}$ and NPV)

\begin{tabular}{lccccccc}
\hline \multicolumn{1}{c}{ Treatment } & Year & $\mathrm{B} / \mathrm{C}$ & $\mathrm{B} / \mathrm{C} @ 50 \%$ & $\mathrm{~B} / \mathrm{C} @ 75 \%$ & $\mathrm{NPV}$ & $\mathrm{NPV} @ 50 \%$ & NPV @ 75\% \\
\hline Teak+ ginger+NPK & 1 & 0.20 & 0.40 & 0.80 & $-2,4213.6$ & $-9,084.54$ & $-1,520.03$ \\
& 2 & 0.98 & 1.95 & 3.90 & -139.38 & $2,782.96$ & $4,244.12$ \\
Teak + ginger & 1 & 0.32 & 0.64 & 1.28 & $-19,147.5$ & $-5,071.54$ & $1,966.41$ \\
& 2 & 1.02 & 2.04 & 4.08 & 92.49 & $2,383.45$ & $3,528.93$ \\
Ginger+NPK & 1 & 0.04 & 0.08 & 0.17 & $-29,016.2$ & $-13,868.2$ & $-6,294.21$ \\
Ginger only & 2 & 0.05 & 0.54 & 1.09 & $-28,644.8$ & $-1,320.48$ & 146.37 \\
& 1 & 0.50 & 1.00 & 1.99 & $-14,172.7$ & -96.79 & $6,941.16$ \\
& 2 & 1.09 & 2.18 & 4.35 & 403.31 & $2,694.27$ & $3,839.75$ \\
\hline
\end{tabular}

Table 6. Sensitivity analysis of increasing benefits of ginger in teak plantation at ibadan (B/C and NPV)

\begin{tabular}{|c|c|c|c|c|c|c|c|c|c|c|c|}
\hline Treatment & Year & $\mathrm{B} / \mathrm{C}$ & $\begin{array}{c}\mathrm{B} / \mathrm{C} @ \\
50 \%\end{array}$ & $\begin{array}{c}\text { B/C @ } \\
75 \%\end{array}$ & $\begin{array}{c}\text { B/C@ } \\
100 \%\end{array}$ & $\frac{\mathrm{B} / \mathrm{C} @}{150 \%}$ & NPV & $\begin{array}{c}\text { NPV@ } \\
50 \%\end{array}$ & $\begin{array}{c}\text { NPV@ } \\
75 \%\end{array}$ & $\begin{array}{c}\text { NPV@ } \\
100 \%\end{array}$ & $\begin{array}{c}\text { NPV@ } \\
150 \%\end{array}$ \\
\hline Teak + ginger & 1 & 0.20 & 0.30 & 0.35 & 0.40 & 0.50 & $-24,213.6$ & $-21,191.3$ & $-19,680.2$ & $-18,169.1$ & $-15,146.8$ \\
\hline$+\mathrm{NPK}$ & 2 & 1.00 & 1.46 & 1.71 & 1.95 & 2.44 & 139.38 & $2,713.27$ & $4,139.59$ & $5,565.91$ & $8,418.56$ \\
\hline \multirow[t]{2}{*}{ Teak + ginger } & 1 & 0.32 & 0.48 & 0.56 & 0.64 & 0.80 & $-19,147.5$ & $-4,645.3$ & $-12,394.2$ & $-10,143.1$ & $-5,640.9$ \\
\hline & 2 & 1.02 & 1.53 & 1.79 & 2.04 & 2.55 & 92.49 & $2,429.7$ & $3,598.30$ & $4,766.91$ & $7,104.11$ \\
\hline \multirow[t]{2}{*}{ Ginger+NPK } & 1 & 0.04 & 0.06 & 0.07 & 0.08 & 0.11 & $-29,016.2$ & $-28,376.3$ & $-28,056.4$ & $-27,736.4$ & $-27,096.7$ \\
\hline & 2 & 0.27 & 0.41 & 0.48 & 0.55 & 0.69 & $-4,254.18$ & $-3,447.57$ & $-3,044.27$ & $-2,640.96$ & $-1,834.35$ \\
\hline \multirow[t]{2}{*}{ Ginger only } & 1 & 0.50 & 0.75 & 0.87 & 1.00 & 1.24 & $-14,172.7$ & $-7,183.15$ & $-3,688.37$ & -193.59 & $6,795.97$ \\
\hline & 2 & 1.09 & 1.63 & 1.90 & 2.18 & 2.72 & 403.31 & $2,895.92$ & $4,142.23$ & $5,388.53$ & $7,881.15$ \\
\hline
\end{tabular}

Table 7. Profitability of ginger rhizome yield $\left(648 \mathrm{~m}^{2}\right)$ in and outside teak plantation in ife

\begin{tabular}{|c|c|c|c|c|c|c|c|c|c|c|}
\hline \multirow[b]{2}{*}{ Treatments } & \multicolumn{7}{|c|}{ Costs } & \multicolumn{3}{|c|}{ Benefits } \\
\hline & Year & $\begin{array}{c}\text { Land } \\
\text { Preparation }\end{array}$ & $\begin{array}{l}\text { Planting } \\
\text { stock }\end{array}$ & Weeding & $\begin{array}{c}\text { NPK } \\
\text { Fertilizer }\end{array}$ & Harvesting & $\begin{array}{l}\text { Total } \\
\text { cost }\end{array}$ & $\begin{array}{l}\text { Rhizome } \\
\text { yield }(\mathrm{kg})\end{array}$ & $\begin{array}{l}\text { Sales price } \\
(80 / \mathrm{kg})\end{array}$ & $\begin{array}{l}\text { Profit } \\
\text { margin }\end{array}$ \\
\hline Teak + ginger & 1 & 2,050 & 231.60 & 300 & 256.74 & 200 & $3,038.34$ & 5.28 & 422.40 & $-2,615.94$ \\
\hline$+\mathrm{NPK}$ & 2 & 800 & 231.60 & 300 & 256.74 & 200 & $1,788.34$ & 5.83 & 466.40 & $-1,321.94$ \\
\hline \multirow[t]{2}{*}{ Teak + ginger } & 1 & 2,050 & 231.60 & 300 & - & 200 & $2,781.60$ & 5.54 & 443.2 & $-2,338.40$ \\
\hline & 2 & 800 & 231.60 & 300 & - & 200 & $1,531.60$ & 8.61 & 688.8 & -842.80 \\
\hline \multirow[t]{2}{*}{ Ginger+NPK } & 1 & 2,050 & 231.60 & 300 & 260.70 & 200 & $3,042.30$ & 30.59 & $2,447.20$ & -595.10 \\
\hline & 2 & 800 & 231.60 & 300 & 260.70 & 200 & $1,792.30$ & 6.26 & 500.80 & $-1,291.50$ \\
\hline \multirow[t]{2}{*}{ Ginger only } & 1 & 2,050 & 231.60 & 300 & - & 200 & $2,781.60$ & 20.95 & $1,676.00$ & $-1,105.60$ \\
\hline & 2 & 800 & 231.60 & 300 & - & 200 & $1,531.60$ & 17.36 & $1,388.80$ & -142.80 \\
\hline
\end{tabular}

ments; ginger grown in teak plantation with NPK fertilizer during second cropping season (0.98), ginger grown in teak plantation without NPK in the second cropping season (1.02) and ginger grown solely outside plantation (1.09). When the cost decreased by $75 \%$, the $\mathrm{B} / \mathrm{C}$ ratios were viable for all the treatments (B/C ranges between 0.80 and 4.35 ) except one, ginger grown outside teak plantation in first season was not viable (0.17), this is could be traced to disturbances on the plot. However, the Net Present Value (NPV) of ginger production was positive for six of the eight treatments when the cost was decreased by $75 \%$ as shown in Table 5 . The NPV ranges between N146:37k and N6941:16k.

On the other hand, increasing benefits by $150 \%$ with no changes in production cost (Table 6 ), $\mathrm{B} / \mathrm{C}$ ratios of five out 
of eight treatments were viable, value ranges between 0.80 and 2.72. NPV at $150 \%$ increased benefits showed four out of eight treatments to be viable, NPVs range between N6795:97k and N8418:56k per hectare.

\section{Profitability analysis of ginger grown under and out- side teak plantations in Ife}

Profitability analysis of ginger rhizome production under Teak canopy in Ife study site was negative in all the treatments (Table 7).

\section{Benefit Cost analysis of ginger grown under and outside teak plantations in Ife}

Benefit Cost analysis of the ginger rhizome production in Ife showed that ginger grown in plots outside teak plantation were viable (Table $8, \mathrm{~B} / \mathrm{C} \geq 1$ ). The highest $\mathrm{B} / \mathrm{C}$ ratios ( 0.60 and 0.91$)$ were observed for plots containing only ginger outside teak canopy in first and second cropping sea- sons respectively, ginger grown in plots within teak plantation without NPK fertilizer gave $\mathrm{B} / \mathrm{C}=0.80$ in the second cropping season at Ife study site.

\section{Sensitivity analysis of Benefit Cost ratios $(B / C)$ and Net Present Values (NPV) of ginger rhizome pro- duction in and outside teak plantation in Ife}

Benefit Cost analysis (Table 9) revealed two treatments to be viable; ginger grown outside teak plantation with NPK fertilizer in first cropping season (0.80) and ginger grown outside teak plantation without NPK in the second cropping season (0.91). When the cost decreased by $75 \%$, the $\mathrm{B} / \mathrm{C}$ ratios were viable in six out of eight treatments with values ranging between 1.04 and 3.63.

However, the Net Present Value (NPV) of ginger production was positive in six of the eight treatments when the cost was decreased by 75\% (Table 9). The NPV was between N95:01k and N13836:59k.

Table 8. Benefit cost analysis of ginger rhizome yield $\left(648 \mathrm{~m}^{2}\right)$ in and outside teak plantation in ife

\begin{tabular}{lccccccccccc}
\hline Treatments & Year & $\begin{array}{c}\text { Total } \\
\text { cost }\end{array}$ & \multicolumn{2}{c}{$\begin{array}{c}\text { Total benefit } \\
(80 / \mathrm{kg})\end{array}$} & $\begin{array}{c}\text { Discount } \\
\text { rate }\end{array}$ & \multicolumn{1}{c}{$\begin{array}{c}\text { Discounted } \\
\text { factor }\end{array}$} & $\begin{array}{c}\text { Discounted } \\
\text { cost }\end{array}$ & $\begin{array}{c}\text { Discounted } \\
\text { benefit }\end{array}$ & B/C & RORI & NPV \\
\hline Teak+ ginger & 1 & $3,038.34$ & 422.4 & 0.8772 & 1.8772 & $1,618.548903$ & 225.0159812 & 0.139023 & -86.0977 & $-1,393.53$ \\
+ NPK & 2 & $1,788.34$ & 466.4 & 0.7695 & 3.1311303 & 571.1483896 & 148.9557964 & 0.260801 & -73.9199 & -422.193 \\
Teak+ ginger & 1 & $2,781.6$ & 443.2 & 0.8772 & 1.8772 & $1,481.781377$ & 236.0963137 & 0.159333 & -84.0667 & $-1,245.69$ \\
& 2 & $1,531.6$ & 688.8 & 0.7695 & 3.1311303 & 489.1524394 & 219.9844609 & 0.449726 & -55.0274 & -269.168 \\
Ginger+NPK & 1 & $3,042.3$ & $2,447.2$ & 0.8772 & 1.8772 & $1,620.658427$ & $1,303.643725$ & $0.804391 *$ & -19.5609 & -317.015 \\
& 2 & $1,792.3$ & 500.8 & 0.7695 & 3.1311303 & 572.4131087 & 159.9422445 & 0.279418 & -72.0582 & -412.471 \\
Ginger only & 1 & $2,781.6$ & 1,676 & 0.8772 & 1.8772 & $1,481.781377$ & 892.8190923 & $0.602531 *$ & -39.7469 & -588.962 \\
& 2 & $1,531.6$ & $1,388.8$ & 0.7695 & 3.1311303 & 489.1524394 & 443.5459049 & $0.906764 *$ & -9.32358 & -45.6065 \\
\hline
\end{tabular}

Note: The current (2011) Central Bank of Nigeria (CBN) discount rate approved for agricultural based investment was used in the calculation.

Table 9. Sensitivity analysis of decreasing cost of ginger in teak plantation at ife (B/C and NPV)

\begin{tabular}{|c|c|c|c|c|c|c|c|}
\hline Treatment & Year & $\mathrm{B} / \mathrm{C}$ & B/C@50\% & B/C@75\% & NPV & NPV@50\% & NPV@75\% \\
\hline \multirow[t]{2}{*}{ Teak + ginger $+\mathrm{NPK}$} & 1 & 0.14 & 0.28 & 0.56 & $-21,460.4$ & $-8,997.55$ & $-2,766.14$ \\
\hline & 2 & 0.26 & 0.52 & 1.04 & $-6,501.74$ & $-2,103.9$ & 95.01 \\
\hline \multirow[t]{2}{*}{ Teak + ginger } & 1 & 0.16 & 0.32 & 0.64 & $-19,183.3$ & $-7,773.81$ & $-2,068.9$ \\
\hline & 2 & 0.45 & 0.90 & 1.80 & $-4,145.18$ & -378.72 & $1,504.52$ \\
\hline \multirow[t]{2}{*}{ Ginger+NPK } & 1 & 0.80 & 1.61 & 3.22 & $-4,882.01$ & $-7,597.06$ & $13,836.59$ \\
\hline & 2 & 0.28 & 0.56 & 1.12 & $-6,352.05$ & $-1,944.48$ & 259.31 \\
\hline \multirow[t]{2}{*}{ Ginger only } & 1 & 0.60 & 1.21 & 2.41 & $-9,070$ & $2,339.70$ & $8,044.56$ \\
\hline & 2 & 0.91 & 1.81 & 3.63 & -702.34 & $3,064.13$ & $4,947.37$ \\
\hline
\end{tabular}


Table 10. Sensitivity analysis of increasing benefits of ginger in Teak plantation at Ife (B/C and NPV)

\begin{tabular}{|c|c|c|c|c|c|c|c|c|c|c|c|}
\hline Treatment & Year & $\mathrm{B} / \mathrm{C}$ & $\begin{array}{c}\mathrm{B} / \mathrm{C} @ \\
50 \%\end{array}$ & $\begin{array}{c}\text { B/C @ } \\
75 \%\end{array}$ & $\begin{array}{c}\text { B/C@ } \\
100 \%\end{array}$ & $\begin{array}{c}\text { B/C @ } \\
150 \%\end{array}$ & NPV & $\begin{array}{c}\text { NPV@ } \\
50 \%\end{array}$ & $\begin{array}{c}\text { NPV@ } \\
75 \%\end{array}$ & $\begin{array}{c}\text { NPV@ } \\
100 \%\end{array}$ & $\begin{array}{c}\text { NPV @ } \\
150 \%\end{array}$ \\
\hline Teak + ginger & 1 & 0.14 & 0.21 & 0.24 & 0.28 & 0.35 & $-21,460.4$ & $-19,727.7$ & $-18,861.4$ & $-17,995.1$ & $-16,262.5$ \\
\hline$+\mathrm{NPK}$ & 2 & 0.26 & 0.39 & 0.46 & 0.52 & 0.65 & $-6,501.74$ & $-5,354.97$ & $-4,781.63$ & $-4,207.81$ & $-3,060.84$ \\
\hline \multirow[t]{2}{*}{ Teak + ginger } & 1 & 0.16 & 0.24 & 0.28 & 0.32 & 0.40 & $-19,183.3$ & $-17,365.6$ & $-16,456.6$ & $-15,547.6$ & $-13,729.7$ \\
\hline & 2 & 0.45 & 0.67 & 0.79 & 0.90 & 1.12 & $-4,145.18$ & $-2,451.3$ & $-1,604.4$ & -757.4 & 936.45 \\
\hline \multirow[t]{2}{*}{ Ginger+NPK } & 1 & 0.80 & 1.21 & 1.41 & 1.61 & 2.01 & $-4,882.01$ & $5,156.08$ & $10,175.1$ & $15,194.12$ & $25,232.18$ \\
\hline & 2 & 0.28 & 0.42 & 0.49 & 0.56 & 0.70 & $-6,352.05$ & $-5,120.48$ & $-4,504.7$ & $-3,888.95$ & $-2,657.4$ \\
\hline \multirow[t]{2}{*}{ Ginger only } & 1 & 0.60 & 0.90 & 1.05 & 1.21 & 1.51 & $-9,070$ & $-2,195.29$ & $1,242.06$ & $4,679.42$ & $11,554.12$ \\
\hline & 2 & 0.91 & 1.36 & 1.59 & 1.81 & 2.27 & -702.34 & $2,712.97$ & $4,420.60$ & $6,128.27$ & $9,543.57$ \\
\hline
\end{tabular}

On the other hand, when the benefits were increased by $150 \%$ without any changes in production cost (Table 10), $\mathrm{B} / \mathrm{C}$ ratios of four out of eight treatments became viable with values between 1.12 and 2.27. NPV at $150 \%$ increased benefits showed four out of eight treatments to be viable, NPVs range between N936:45k and N25232:18k per hectare.

\section{Discussions}

\section{Effect of Teak plantation and NPK fertilizer on rhi- zome yield of ginger}

Closed canopy teak plantation inhibits ginger rhizome yield. Higher yields were recorded in ginger plots located outside the plantation both in Ibadan and Ife sites (Fig. 1). Inhibitory effect of the canopy on tillerring, height, foliar production and inadequate light intensity reduce the photosynthetic activity of the plant. This in turn reduced ginger rhizome yield which acts as the storage organ for the plant. Ginger grown outside the plantation produced higher number of tillers, heights and increased foliage which enhanced photosynthetic activity and consequently increase rhizome yield in ginger. Adequate nutrient availability in the soil is required for optimal yield in ginger rhizome, nitrogen enhance vegetative growth while potassium facilitate rhizome yield in ginger (Sadanandan et al. 2001). This finding is consistence with results of Ogunkunle and Awotoye (2011) that soil under the sole cropping of teak in southwest Nigeria was impoverished due to the high rate of nutrient uptake of the teak. Soils of teak plantation in Nigeria decline in carbon, nitrogen, calcium, magnesium and organic matter due to annual burning (Oseni et al. 2009), this scenario of loss of vital nutrients affect ginger stands and invariably low rhizome yield under the plantation. Kumar (2011) reported that nutrient immobilisation and/or leaching may be important in stopping the fertilizer response in teak plantation, also increased rate of nutrient recycling reduce the use efficiency of inorganic nutrients such as NPK, and lead to their reduced retention especially under low soil organic matter levels. Allelopathic nature of teak plantation (Thomas et al. 1999) exerts negative influence on the effective growth of ginger.

Although ginger is known to be shade tolerant species (Sasikumar et al. 2008; Valenzuela 2011), 25\% light intensity is required for optimum ginger growth, $53 \%$ shade in Populus deltoids gave reduced yield in ginger (Jaswal et al. 1993) hence; the degree of shade in teak plantation is an important factor in the use of ginger as possible understory species in multiple forest production practices.

NPK fertilizer applied in double dosage enhanced rhizome yield in ginger grown outside the plantation (Fig. 1) as opposed to findings in the teak plantation. NPK fertilizer is known to enhance vegetative growth in plants (Valenzuela 2011) which facilitates plant photosynthetic activity and increased rhizome yield.

\section{Profitability of ginger production in and outside teak canopy in southwestern Nigeria}

Inputs in agricultural business have been identified to be substantial in the production costs (Olawepo 2010) and greatly reduce farmers' income. Cost of inorganic fertilizer and other inputs in ginger rhizome production reduced the profit considerably; hence ginger production in teak plantation was not financially profitable from the study (Tables 3 
and 7). However, consideration of other benefits such as reduction in routine plantation maintenance cost, environmental services and increase in wood/biomass yield during ginger production period could suffice in lieu of direct monetary profits. Sole production of ginger with little or no farm inputs yielded marginal financial profit N82 per 648 $\mathrm{m}^{2}$ of land at Ibadan, no profit was recorded at Ife study site. Peasant and subsistence farmers have no proper financial records, especially cost of family labour and rent on land; hence subsistence cycle remains and majority of rural farmers live below poverty line (Okuneye 2002).

\section{Benefit Cost and Sensitivity analysis of ginger pro- duction in and outside teak canopy in southwest- ern Nigeria}

Benefit cost analysis indicate the viability of a project considering both monetary and non-monetary benefits as well as costs over a specified time period. Benefit cost analysis showed that ginger grown outside teak plantation was most viable $(\mathrm{B} / \mathrm{C}=1.09)$ in the second year at Ibadan, similar result was obtained in Ife study site $(\mathrm{B} / \mathrm{C}=1.0)$. All the ginger plots under teak canopy were not viable; $(\mathrm{B} / \mathrm{C}<1)$. The sensitivity analysis of $\mathrm{B} / \mathrm{C}$ at $75 \%$ decreased cost showed that ginger production under teak canopy will be viable in financial terms if the cost of production is reduced by about $75 \%$. At Ibadan site sensitivity analysis of the B/C at $75 \%$ decreased cost of production in ginger showed $\mathrm{BC}=0.80-4.08$ for plots under canopy and 1.09-4.35 for plots located outside teak canopy (Table 5 ). While sensitivity analysis of $\mathrm{B} / \mathrm{C}=1.04-1.8$ for plots under canopy and 1.12-3.63 for plots outside teak canopy at Ife (Table 9). This sensitivity result showed that cost of inputs is a constraint in financial profitability and viability of growing ginger in a multiple land use system with teak. Research efforts and policy should be geared toward production cost reduction in multiple uses of plantation forest for maximum benefits.

Sensitivity analysis of the $\mathrm{B} / \mathrm{C}$ based on increasing benefits up to $150 \%$ showed a similar trend of viability for the two sites (Tables 6 and 10). Increase in benefits in terms of improved marketing, transportation, appropriate pricing and improved farm practices that will lead to increase in yield, that can reduce farmers' poverty level are important for profitable ginger rhizome production in teak planta- tions, southwestern Nigeria.

\section{Conclusion}

The study revealed that ginger could be used as non timber component of a multiple forest management in teak plantations based on improved benefits and reduced production costs. Forest plantations safety and maintenance will reduce substantially in association with improved livelihood of peasant rural populations adjoining forest estates through employment and cash income. Further studies are required on the performance of ginger under different teak canopy closure level and different tree species. Also, private tree growers in plantation forestry can explore the economic potentials of compatible forest undergrowth at canopy closure.

\section{References}

Adepoju AA, Salau AS. 2007. Economic Valuation of NonTimber Forest Products (NTFPs), Munich Personal RePEc Archives MPRA. http://mpra.ub.uni-muenchen.de/2689/. Accessed 5 Sep 2011.

Adesoye PO, Oluwadare AO. 2010. Interim Crown Ratio Models for a Tectona grandis and Gmelina arborea stand in the University of Ibadan, Nigeria. Res J Forestry 4: 110-118.

Agbola T, Ojeleye D. 2007. Climate change and food crop production in Ibadan, Nigeria. African Crop Science conference Proceedings, Vol. 8, pp 1423-1433. $8^{\text {th }}$ African Crop Science Society Conference, 27 October 2007, El-Minia, Egypt

Agyeman VK, Marfo KA, Kasanga KR, Danso E, Asare AB, Yeboah OM, Agyeman F. 2003. Revising the taungya plantation system: new revenue-sharing proposals from Ghana. Unasylva No. 212 - Making forestry pay. Int J Forestry and Forest Industries 54 (1). FAO

Amusa TO, Jimoh SO, Azeez IO. 2012. Determining the Local Importance of Non-Timber Forest Products Using Two Different Prioritization Techniques. Int J Agric Forestry 2: 84-92.

Brown C. 2000. The global outlook for future wood supply from forest plantations. Global Forest Products outlook study, working paper series. No: GFPOS/WP/03 FAO.

Chukwuone NA, Okorji CE. 2008. Willingness to pay for systematic management of community forests for conservation of Non-Timber forest products in Nigeria's rain forests region; Implication for poverty alleviation. In: Proceedings of the Frontis workshop on Economics of Poverty, Environment and Natural Resource use (Rob BD, Ruijs A, eds). Wageninging, The Netherlands, Springer Publishers, pp 117-137. 
Clark L. 2001. Non-Timber Forest Products Economics and Conservation Potential. Congo Basin Information Services. Issue brief No. 10, CARPE. http://carpe.umd.edu. Accessed 15 Feb 2011.

Evans WC. 1999. Trease and Evans Pharmacognosy. WB Saunder Company Ltd, London.

Jaswal SC, Mishra VK, Verma KS. 1993. Intercrop ping ginger and turmeric with poplar (Populus deltoids 'G-3' Marsh.). AF Sys 22: 111-117.

John SS. 1980. Can farming and forestry coexist in the tropics? (In) Co-Existence Forestry and farming. Unasylva 32: 2-3.

Johnson D. 1980. Tree crops and tropical development; the oil palm as a successful example. Agric Adm 7: 107-112.

Krishnapillay DB. 2002. Forest Plantations Working Papers - Case Study of the Tropical Forest Plantations in Malaysia. In: Varmola M, ed. FAO Working Paper FP/23, Rome.

Kumar BM. 2011. Soil management in teak plantations. In: Innovations in the Management of Planted Teak Forests (Jayaraman K, Bhat KV, eds). Proceedings of the International Training Programme, Kerala Forest Research Institute, Peechi, India, 31 August- 3 September 2011.

Lee MT, Asher CJ, Whiley AW. 1981. Nitrogen nutrition of ginger (Zingiber officinale). Effect of Nitrogen supply on growth and development. Field Crops Res 4: 55-68.

Ogunkunle CO, Awotoye OO. 2011. Soil Fertility Status under Different Tree Cropping System in a Southwestern Zone of Nigeria. Not Sci Biol 3: 123-128.

Okuneye PA. 2002. Rising cost of food prices and food insecurity in Nigeria and its implications for poverty reduction. CBN
Economic \& Financial Review, Vol. 39 No. 4.

Olawepo RA. 2010. Determining rural farmers' income: A rural Nigeria experience. J Afr Studies and Dev 2: 99-108.

Oseni OA, Ekperigin MM, Oboh G, Akindahunsi AA, Adekunle VAJ. 2009. Effects of fire on physico-chemical properties and proteolytic enzyme activities of soil from teak (Tectona grandis L.F) plantations. J Agric Biotech and Sust Dev 3: 79-85.

Sabur SA, Molla AR. 1993. Trend, Variability and Relative Profitability of spices in Bangladesh. Bangladesh J Agric Econs XVI 1 (June 1993): 1-5.

Sadanandan AK, Peter KV and Hamza S. 2001. Role of Potassium Nutrition in Improving Yield and Quality of Spice Crops in India. Paper presented at International Potassium Institute conference on nutrient management for sustainable crop production in India, New Delhi, India.

Sasikumar B, Thankamani CK, Srinivasan V, Devasahayam S, Santhosh JE, Kumar A, John ZT. 2008. Ginger Extension Pamphlet. In: Srinivasan V, Thankamani CK, Dinesh R, Kandiannan K, Rajeev P, eds. Indian Institute of Spices Research, Kerala, India.

Thomas SC, Halpern CB, Falk DA, Liguori DA, Austin KA. 1999. Plant diversity in managed forests: understory responses to thinning and fertilization. Ecol Appl 9: 864-879.

Tyler VE, Brady LR, Robbers JE. 1981. Pharmacognosy. Lea \& Febiger Publishers, Philadelphia, USA.

Valenzuela H. 2011. Farm and Forestry Production and Marketing Profile for Ginger (Zingiber officinale) revised. In: Specialty Crops for Pacific Island Agroforestry (Elevitch CR, ed). Permanent Agriculture Resources (PAR), Holualoa, Hawai'i. 